\title{
The Effectiveness of Quantum Learning Method to Students' English Learning Achievement at SMK N 9 Padang
}

\author{
Zia Syukria ${ }^{1}$ \\ ${ }^{1}$ English Education Section, Graduate Program State University of Padang \\ Correspondence email: zia_syukria26@yahoo.com
}

\begin{abstract}
Abstrak. Tujuan penelitian ini untuk mengetahui keefektifan belajar dengan menggunakan metode pembelajaran kuantum terhadap hasil belajar siswa pada mata pelajaran Bahasa Inggris. Penelitian ini menggunakan jenis penelitian pre-experimen, dengan tipe one group pre-test post-test. Partisipan penelitian ini adalah siswa kelas X Perhotelan 3 di SMK N 9 Padang yang berjumlah 27 orang. Instrumen yang digunakan sebagai alat pengumpul data adalah tes. Hasil penelitian menunjukkan keefektifan penggunaan metode quantum learning yang dapat dilihat dari nilai hasil belajar siswa. Temuan penelitian ini menunjukkan bahwa; penggunaan metode pembelajaran kuantum efektif untuk meningkatkan hasil belajar Bahasa Inggris siswa pada materi "announcement", dapat dilihat dari uji $t_{\text {observed }} 5,17$ lebih besar dari $t_{\text {table }} 2,060$.
\end{abstract}

Kata kunci: Bahasa Inggris; Hasil belajar; Metode pembelajaran kuantum

\section{INTRODUCTION}

Teachers always try to transfer the knowledge by various innovations in learning. The fact shows that many teachers face the challenge of doing the teaching and learning activities in the classroom. Therefore, the teacher as an educator should be able to attract and motivate students to learn. Teachers are required to be able to create a fun learning activities by varied methods, appropriate learning approaches, and learning media that are relevant to the material that will be taught to improve students' comprehension and achievement.

Learning achievement is an illustration of how students understand the material conveyed by the teacher. From the achievement, teacher can get information on how the students understand the material that has been studied. Learning achievement become standard for the success of students in learning the material delivered by the teacher. Learning objectives are considered to be achieved if students get satisfying learning achievement. It can be known after the teacher evaluates students learning achievement.

Achievement is the important thing to measure how far our effort and skill can be reach. It is as a result of activities that have been done, especially by students in learning. According to Winkel (1996), learning achievement is the capabilities resulting from the effort to learn. He also says that learning achievement is a testament to the success that has been achieved by student.

Learning achievement can be measured in three aspects: cognitive, affective and psychomotor. Anderson and Krathwohl (2001) states that cognitive aspect relate to the results of intellectual learning that consists of six aspects: remembering, understanding, applying, analyzing, creating, and evaluation. Affective includes character behaviors such as receiving or attending, responding, valuing, organization, and characterization. Psychomotor is related to skills or the ability to act after someone receives a specific learning experience. Measuring students' cognitive aspect can be done in various ways, either by a written test, oral test or practice (Syah: 2010). Oral and practical tests are rarely used by teachers because the number of students is quite a lot in the classroom. Cognitive most rated by teachers as it relates to students' ability in mastering the materials.

Learning achievement is very important because the success of learning carried out in teaching and learning activities can be seen from student learning achievement. Learning achievement is the results achieved by students after learning activities. Low students' learning activities also cause to low understanding and mastery of learning material and give affect to students' learning achievement.

The method used by the teacher during teaching and learning process can affect the level of students learning achievement. There are several learning methods that have been created by experts, one of the exciting learning methods called quantum learning method. Quantum learning method is one of learning method created by Potter that aims to create fun classroom atmosphere and make students enthusiastic to learn.

In English subject, Quantum learning had been used to know the implementation of this method in English learning at SMA N 1 Grobogan. The research was conducted by Suprastijono (2015), he told that the obstacles when using quantum learning are the facilities were less available, the time run out in apperception and motivation, and students sometimes crowded and unfocused in learning. Besides, he did not focus on one aspect, there are many aspects that he research like the preparation of learning with quantum learning, the implementation of quantum learning, the result of learning, and problems and the way to overcome the problems. There is a similarity of research conducted by Suprastijono with the research that has been carried out, that was describing the effects of quantum learning on student learning in secondary schools, but the difference is if suprastijono's research was to describe the application of quantum learning method in English learning and used qualitative method, while the research that has been conducted by the researcher focused on learning achievement and activities, and used experimental research.

Another researcher is Khasanah (2012) found the the implementation of quantum learning can improve the students' reading skill and identified the class situation 
when quantum learning was implemented in reading class at eight grade students of SMP Negeri 16 Surakarta. It is difference with researcher that describe the students' English learning activities when quantum learning was implemented in the classroom.

Then Saragih and Kristiani (2012) who investigated the effect of applying quantum learning on the students' achievement in writing argumentation. The objective of the study was to find out whether the application quantum learning gives effect to students' achievement in writing argumentation. The result of research indicated that there was an effect on the students' achievement in writing argumentation, which was taught by using Quantum Learning than using conventional method. There are several differences between this research with the research that has been carried out, including this research using comparative classes that was taught by conventional methods, besides this research focuses on writing argumentation.

There are some phenomena related to the reason why the researcher did the research on the using of quantum learning method. Nowadays, English teachers have to fulfill many curriculum objectives of teaching and learning in a short time. Planning time may affect to achievement of learning objectives and students' understanding. Then, some of students usually get bored with activities undertaken in the classroom. Students' boredom sometimes caused by mismatch of teaching methods with students' learning styles. An effective way for teachers to accommodate students' learning styles is using appropriate teaching method and media that can notice all of students' learning styles.

Quantum learning is a combination of some learning methods. They are Suggestopedia (Accelerated Learning), Neuro Linguistic Program (NLP), and its own method (Deporter \& Hernacki: 2013). The combination of positive suggestion, busting obstacles in learning, and theories about how human's brain works makes this learning method deserves to be implemented in the classroom.

Quantum learning method is an effective way for classroom management, focusing attention, and motivating students to increase participation in learning (DePorter:1999). Quantum learning method focuses on accelerated learning with a high level of success. It helps teachers to create conducive classroom atmosphere for students, so that students can maximize their brain's ability to learn. Beside that, quantum learning will change learning situation from learning with effort into learning with fun.

Teaching and learning process should give comfort and joyful atmosphere for the students. According to Walberg and Greenberg in DePorter (1999) good atmosphere will lead good emotion of the students. This good emotion will accelerate their learning. It is important for the teacher to create good atmosphere that make the students feel safe but challenged, understood, and celebrated.

The learning design in quantum learning consisting of six stages is bound to correlative and mutual complementarily principle. The design called EEL Dr.C, namely: Enroll, Experience, Label, Demonstrate, Review, and Celebrate. Enroll is grow the students' interest or motivation, and tell the benefits of learning. Experience is to create learning experience to which all students can be involved. Label is to give name or key words to the topic being taught. Demonstrate or give opportunity to the students to show that they know and understand. Review is the stage where the knowledge and skills gained are nailed in brain. Last, the teacher will celebrate their students' success.

Quantum learning focuses on using teaching strategies better suited to hardwiring data into students' long term memory. This can be achieved through a number of different activities that appropriate with model of students learning (visual, audio, and kinesthetic) and methods. Quantum learning can be participatory learning by students in seeing their potential. Learning style with reference to the right brain and left brain is a hallmark of quantum learning.

Students learn in many different ways or learning style. Jahiel (2008) defined learning styles as the way in which individuals process information and analyze it. According to Jahiel, individuals do not rely on one type of learning styles but some of them have one primary learning style and others have more than one learning style.

A learning style is the unique collection of individual skills and preferences that affect how a person perceives, gathers, and processes information. Each of us has our own preferred way of learning that is determined by our cultural, educational background, and our personalities. Language researchers have categorized the various learning styles in numerous ways. Some researchers have divided into three categories: visual learners, auditory learners, and kinesthetic learners.

Visual learners learn visually by means of read words and see images, maps, and graphics. People learn better from words and pictures than from words alone. It can be said that using both words and pictures is more effective than words alone. Students with auditory style will be able to recall what they hear and will prefer oral instructions. They have difficulty with reading and writing tasks. Auditory learners learn best through verbal lectures, discussions, talking things through and listening to what others have to say. Kinesthetic learners learn by doing or making something. They have good memory skill by doing body's movement and emotional touch. They tend to lose concentration if there is little or no external stimulation or movement.

It is important for teachers to understand the differences in their students' learning styles, so that this learning styles should be considered in learning process, including the selection and use of media that will be set and method that will be used. In this case, quantum learning method with interactive multimedia that is focuses on students' long term memory may serve to meet the needs of students with difference learning styles.

Learning activity becomes more active with quantum learning method, as well as the potential to give meaning to the learning process and increase student interest. The study about Quantum Learning application in Drake University (2011) shows that Quantum Learning increased students' motivation 
(68\%), improved grades (73\%), developed more confidence (81\%), increased self-esteem (84\%), and continued to use skills $(98 \%)$. It is hoped that the use of quantum learning method can also produce the expected result in this research.

From those factual fact above, it is assumed that quantum learning is an one of the effective method to be applied in teaching and learning English. The purpose of this research is to find out the effectiveness of using quantum learning method to students' English learning achievement at SMK N 9 Padang.

\section{METHOD}

This research used pre-experimental design in the form of one group Pretest- Posttest. This design had a purpose to find out the differences between before and after teaching by using quantum learning method. In this research. the test would be given twice, before giving treatment called Pre-test and after giving treatment called Post-test.

The researcher used purposive sampling technique. It was based on the teacher recomendation that the students of class $X$ hotel accommodation 3 are more homogeneous than other classes. In X HA 3 class, there are 27 students consist of 15 male and 12 female.

The researcher used test as instrument. To find out the data of English test, the researcher applied Pretest. This test would be used to measure students' grade X HA 3 achievement in SMK N 9 Padang before using quantum learning method. After gaining the Pre-test, the researcher gave the treatment by using quantum learning method. Then, the researcher gave the Posttest to know students' achievement after the treatment. Last, the researcher analyzed and compared score of pre-test and post-test to find out whether there was a different between pre-test and post-test. The test consisted of three parts consisting of fifteen questions in the form of multiple choices, ten questions for match the words, and ten questions in the form of essay. The material of the test was taken from English book related to the subject and based on Vocational High School curriculum.

This research used content validity. Content validity is the content about what we say the test is about. This kind of validity depends on careful analysis of the language being tested. A test is said to have content validity if the contents constitutes a representative sample of the language skill, structures. The researcher constructed the test based on the course objectives in the syllabus of tenth grade in SMK N 9 Padang. The researchers got validity from expert judgment that is Sarah Hediyati Hastuti, M.Pd as the lecturer in University of Dharmas Indonesia. In this case, the expert assessed whether the test that was made by researcher had been representing the content in syllabus.

The validation process began by compiling a test based on the syllabus. Then the research instruments provided to faculty to be consulted about such tests. Further tests improved validation emphasis on the use of language, sentence structure, choice answers, and material. Then, the test item was tried out and the result was computed with Pearson Product Moment correlation formula:

$$
r=\frac{N \sum x y-\left(\sum x\right)\left\{\sum y\right]}{\sqrt{\left.L N \sum x^{2}-\left(\sum x\right)^{2}\right)\left(N \sum y^{2}-\left(\sum y^{2}\right)\right]}}
$$

Where:

$r \quad$ : correlation coefficient

$\mathrm{x} \quad$ : item which its validity is assessed

y $\quad$ : item which its validity is assessed

$\mathrm{N} \quad$ : the number of participants

The researcher found the reliability of each test. For multiple choice and matching test, the researcher used KR-21 formula:

$r_{11}=\frac{k}{k-1}\left[1-\frac{M \times(k-M)}{k \times V a r}\right]$

Where:

$r_{11}=$ index reliability

$\mathrm{k}$ = number of item

$\mathrm{M}=$ mean score of the test

$V a r=$ variance of the test

Then, the reliability of essay test was computed using Alpha formula as follows:

$r_{11}=\left[\frac{n}{n-1}\right]\left[1-\frac{\sum \sigma_{i}^{2}}{\sigma_{t}^{2}}\right]$

Where:

$r_{11}=$ index reliability

$\mathrm{n}=$ number of item

$\sum \sigma_{i}^{2}=$ item variance

$\sigma_{t}^{2}=$ total variance

The researcher found that the reliability $(\alpha)$ of the test was 0,72 for pretest and 0,71 for posttest,it was categorized as high.

The researcher used T-test by using statistical program to ensure the effectiveness and to get stronger conclusion. The T-test would be taken from the result which are conducted before and after the students taught by using quantum learning method. The formulation of T-test as follow (Siregar:2004):

$t=\frac{\bar{x}_{1}-\bar{x}_{2}}{\sqrt{\frac{S_{1}^{2}}{n}+\frac{S_{2}^{2}}{n}}}$

Where:

$\mathrm{t}=\mathrm{t}$ score

$\bar{x}_{1}=$ the mean of post-test

$\bar{x}_{2}=$ the mean of pre-test

$S_{1}^{2}=$ varian of post test

$S_{2}^{2}=$ varian of pre test

$n=$ number of students follow:

The hypotheses of the research is formulated as

$H_{0}$ : Quantum learning method does not efective to English learning achievement of students' grade $X$ HA3 SMK N 9 Padang. 
$H_{a}$ : Quantum learning method effective to English learning achievement of students' grade X HA3 SMK N 9 Padang.

\section{FINDINGS AND DISCUSSION}

Students' average score in pretest was 61,07 . It was under the minimum criteria of achievement (KKM) that is 75 . There were 25 students or $92 \%$ students who had score under KKM and only 2 students who had score above KKM. It means that almost all of the students got low score and it can be conclude that almost all of them did not understand the material and indicate the need of improvement to students' English learning achievement.

In general, the scores of students had increased after the treatment. The students' average during the pretest was 61.07 under $\mathrm{KKM}$, after given treatment, it increased to 72.44 but it still under KKM. There were 11 students or $40 \%$ students who had score above KKM. The lowest score on pretest was 40 and students' lowest score after posttest was 57 . The highest score on pretest was 78, and increased on posttest to 85 . The result of $t_{\text {observed }}$ was 5.17 and the value of $t_{\text {table }}$ was 2.060 with level of significance 0.05 . Since the value of $t_{\text {observed }}$ was bigger than $t_{\text {table }}$, it can be concluded that posttest score higher than posttest score, it was indicate that quantum learning method effective to English learning achievement of students' grade $X$ HA3 SMK $N 9$ Padang.

This is also in line with the purpose of learning English in SMK for; 1) developing of English communication skills, in the form of oral and written. The ability to communicate involves listening, speaking, reading and writing. 2) Growing awareness of the importance of English as a foreign language to be the main tool of learning, 3). Develop an understanding of intercultural and cultural interconnections. Thus students have cross cultural insights and involve themselves in cultural diversity (Kurikulum: 2014). To develop knowledge and skills will be done through active and creative learning. One of the learning methods that can develop active and creative participation in the learning process is the quantum learning method.

The use of quantum learning methods helped the learning process to delivery learning materials. It can help students improve understanding because it presents the material in interesting way. It allows the achievement of learning objectives that can increase students activities so that it affects to students' learning achievement.

According to Gestalt's theory of learning psychology in Djamarah (2008), one of the important elements to improve learning achievement is students learning based on their interests, desires and goals. Learning with quantum learning method is expected to cultivate the interests, desires and goals of students to further improve their achievement in English subjects. It is also reinforced by the theory that argued by DePorter and Hernacki (2011) that the suggestions given in the quantum learning method can influence the learning situation, and any details give positive or negative suggestions by placing students in a comfortable, enhancing individual participation, and fun teachers so that students can learn at an impressive pace, and accompanied by excitement. It can be concluded that the quantum learning method effective on improving student learning achievement and learning activities.

\section{CONCLUSION}

Based on the findings and the discussion above, it can be taken conclusion that the application of quantum learning method effective to students' English learning achievement on the material "announcement" at class $X$ HA3 SMK N 9 Padang. It can be seen from the result of t-test analysis, the value of $t_{\text {observed }}$ was 5.17 and the value of $t_{\text {table }}$ was 2.060 with level of significance 0.05 . The value of $t_{\text {observed }}$ was bigger than $t_{\text {table }}$. This is also shown by result of the students' test after the treatments, the mean score of pretest 61,07 increase to 72,44 in posttest. The students got more improvement, the posttest scores are better than pretest. Thus, it can be said that learning by using quantum learning method give a positive impact for students.

\section{REFERENCES}

Anderson, L. W., \& Krathwohl, D. R. (2001). A Taxonomy for Learning, Teaching and Assessing: A Revision of Bloom's Taxonomy of Educational Objectives: Complete Edition. New York: Longman.

DePorter, B. (1999), 'Quantum Learning: Unleashing the Genius in You'. New York: Dell Publishing.

DePorter, B and Mike Hernacki. (2013). Unleashing The Genius in You. Bandung: Kaifa.

Djamarah, S. Bahri and Zain. A. (2006). Strategi Belajar Mengajar. Jakarta: Rineka Cipta.

Jahiel, J. (2008). What's your learning styles?. Practical Horseman.

Khasanah, E .N. (2012). Improving Students' Reading Skill Using Quantum Learning Method (An Action Research At The Eighth Grade Of Smp Negeri 16 Surakarta In The Academic Year Of 2011/2012). Thesis Surakarta, English Education Program, UNS. Unpublished.

Kristiani, S and Saragih, A. (2012). The Effect of Quantum Learning on The Students' Achievement in Writing Argumentation. Journal of Applied Linguistics of FBS Unimed, 1(1).

Kemdikbud, (2014), Peraturan Menteri Pendidikan dan Kebudayaan, Nomor 57, 58, 59 dan 60 Tahun 2014 tentang Kurikulum SD, SMP, SMA dan SMK.

Siregar, S. (2014). Statistic Parametrik untuk Penelitian Kuantitatif. Jakarta : PT. Bumi Aksara.

Syah, M. (2010). Psikologi Pendidikan dengan Pendekatan Baru. Bandung: PT Remaja Rosdakarya.

Suprastijono. (2015). Implementasi Model Quantum Learning pada Pembelajaran Bahasa Inggris ( Studi Kasus di SMA Negeri 1 Grobogan). Unpublished Thesis of Universitas Sebelas Maret.

Winkel, W.S. (1996) . Psikologi Pendidikan dan Evaluasi Belajar. Jakarta: PT Gramedia. 